DOI https://doi.org/10.30525/978-9934-26-147-3-6

\title{
RESEARCH OF THE MODERN PROCESS OF MANAGEMENT ORGANIZATION UNDER DIFFERENT LEADERSHIP STYLES
}

\author{
Bondarchuk L. V. \\ $P h D$ in Economics, \\ Associate Professor at Department of Management and Administration \\ Vinnytsia Institute of Trade and Economics \\ of Kyiv National University of Trade and Economics \\ Vinnytsia, Ukraine
}

Recently, more and more scholars connect the effectiveness of the organization with the use of a certain style of leadership in management, particularly, analyzing modern approaches to the organization of manager work including public administration system.

Research has identified some links between style, leader type, the effectiveness of the organization and its management culture. In general, they are reduced to the following provisions:

- style reflects the established ways of working of a certain leader type; closely related to the psychological features of his thinking, decision-making, communication, etc .;

- style is not an innate quality, but is formed in the process of activity and changes, it can be adjusted and developed. Leadership styles can also be taught;

- description and classification of styles to some extent reproduce the semantic characteristics (parameters) of management (specifics of the tasks, relationships with subordinates, etc.);

- leadership style is determined by cultural values, traditions of the organization;

- environmental factors (socio-economic, political, socio-psychological, etc.) affect the formation of leadership style.

Thus, the management style and features of the modern organizational process of workplace management depends on many factors, among which the most important are: the nature of the relationship between subordinates and management, structured tasks, the degree of authority of the head, personal qualities of the leader and subordinates, environmental influences, value of decision quality, completeness of information, quality of information flows, consistency of goals of subordinates and general organizational goals, the degree of motivation of subordinates, etc. 
Specifically considering many factors of influencing on leadership style the so-called synthetic theory of leadership is becoming more and more popular, which is based on combination of three components: leader, situation, group. These components interact, and leadership is the result of the interaction of these components [6].

Recently, in scientific research, devoted to the study of effective leadership styles, more and more attention is paid to the psychological characteristics of the leader and his personal characteristics, because the management style is based on the influence of personal characteristics of the head on management decisions. It is proved that while making managerial decisions the manager is under pressure of experience, ideas about values, physical and psychological condition, level of education, expectations of subordinates and management, personality type, risk attitude, personal motives, degree of authority, potential, etc.

The main leadership styles, according to traditional scientific approaches, are authoritarian, democratic and liberal, and accordingly it is defined three types of leaders (autocrat, democrat, liberal).

In recent years, researchers have been inclined to believe that there is no one-size-fits-all leadership style, any of which can be effective depending on the situation. Recognition of the primacy of the situation in the choice of management style was a prerequisite for the formation of the theory of situational management. None of the situational styles is universal, therefore managers need to be flexible, adapting to situations [8].

Statements characterize the most important rules of behavior and attitudes that must be present in the ideal team. In general, they form the standard of the ideal team, in which all participants are overly active.

The results of theoretical and analytical research of leadership and modern interpretation of the process of organizing the workplace of the manager in management allow us to make the following conclusions:

The modernity and features of the system of public administration requires the necessity of extensive use in the practical management activity of the potential of the manager-leader and his leadership qualities, as one of the conditions of the effectiveness of organizations functioning.

The urgency of the problematics and the versatility of the concept of «leadership potential» led to the presence of a significant number of diverse concepts and theories that are systematically used in context of public administration.

The concept of leadership can be divided depending on the aspects of the theoretical basis into three groups:

- Leadership - a universal phenomenon of human activity, the laws of which are unique in all spheres of society. 
- The identity of leadership with the headship and management, at the same time, a formal possession of power is considered as a necessary and sufficient condition of the leadership; the activity of the leader appears as a necessary and sufficient condition of the leadership, while the administrative specificity of the phenomenon is led mainly to the legal regulatory actions of the official. Leadership as a social institution is identified with public authorities

- Consideration of the leadership as a specific phenomenon of public life with the application of psychological, economic or legal principles.

The study of the problem of the leadership is necessary to develop methods of effective leadership, selection and formation of leaders.

Modernity requires a quick and high-quality solution of the problem of the headship and leadership in the organization of manager's work, therefore it is important to study the phenomena of the headship and leadership, adapting the management system to the characteristics of modern leadership.

There are many views on leadership style, but there is no universal, the best that leads to maximum efficiency of the organization, therefore, the task of the leader - such control levers that would create the most effective style appropriate for a particular situation.

The leader's skills is to create a favorable socio-psychological climate in the team, interest employees, apply certain motivational and managerial methods, identify their leadership skills, ability to communicate and resolve conflict situations - all depends on the chosen leadership style and affects the effectiveness of the organization.

Thus, the manager, and the features of the organization of his workplace should stimulate and set goals, determine the means of achieving the goal and methods of control. Successful leadership mostly depends on the ability of the leader to manage the opinion of the team, and form and take into account the management system of the enterprise as a whole.

\section{References:}

1. Andriushchenko A.M., Burliai A.P., Kostiuk V.S., Sereda H.I., Penkova O.H., Krymkovskyi R.B., Mudrak R.P., Fytsyk L.A. Economic theory: textbook. Kyiv: Center of Educational Literature, 2009. 520 p.

2. Beda K.V. Features of functioning and properties of the socio-economic system of the state in terms of economic transformation. Economy and state. 2013. № 9. P.80-81.

3. Bobrovska O.Y., Practically oriented paradigm of public administration in the processes of socio-economic development of Ukraine. Public administration: improvement and development. 2020. № 3. 
URL: http://www.dy.nayka.com.ua/pdf/3_2020/6.pdf (reference date: 29.09.2021)

4. Zahurska-Antoniuk V.F. National security and public administration system. Public administration: improvement and development. 2020. № 5. URL: http://www.dy.nayka.com.ua/pdf/5_2020/59.pdf (reference date: 29.09.2021).

5. Kokotun T. New in public administration reform. Financial control. 2019. № 7. P. 14-17.

6. Mochernyi S.V., Fomishyna V.M., Tyshchenko O.I. Economic theory for managers: Textbook. Kherson: Oldie-plus, 2006. 625 p.

7. Rodchenko I.Y. Priority areas for improving the system of public administration: scientific and practical recommendations in the context of reform. Public administration: improvement and development. 2019. № 2. URL: http://www.dy.nayka.com.ua/pdf/2_2019/32.pdf (reference date: 29.09.2021).

8. Shvebel V., Morozov O. On the complexation of models of socio-economic systems. Economist. 2020. № 4. P. 15-31.

DOI https://doi.org/10.30525/978-9934-26-147-3-7

\section{ЗМІСТ ПУБЛІЧНОГО УПРАВЛІННЯ В ГАЛУЗІ ОСВІТИ}

Галич О. А.

кандидат економічних наук, професор,

перший проректор Полтавського державного аграрного університету

Карапиш С. П.

ЗВО ступеня доктора філософії навчально-наукового інституту економіки, управління, права та інформачійних технологій

Полтавського державного аграрного університету

м. Полтава, Україна

У сучасних умовах розвитку української держави особливої актуальності набуває необхідність впровадження нових підходів до реформування публічного управління освітою як одного із основних напрямів побудови демократичної держави. Свропейська спрямованість розвитку України детермінує потребу в нових, адекватних сучасних умовах реформування та виважених нормативно-правових підходах. На сьогоднішній день вимагають трансформації та удосконалення форми і 